\title{
Article
}

Heath Brown*

\section{Immigrant-Serving Nonprofits and Philanthropic Foundations}

\begin{abstract}
Immigrant-serving nonprofit organizations registered and mobilized thousands of new voters in 2012. These efforts were abetted by philanthropic foundation which, since the early 2000s, have prioritized immigration policy and immigrant issues. Other foundations, hostile to illegal immigration, have funded another set of nonprofits that worked to change immigration policy and voting laws. The article explains these complex relationships between foundations and nonprofits in the context of immigration. The conclusions highlight the tension faced by immigrant-serving nonprofits to maintain their independence and benefit from external funding.
\end{abstract}

Keywords: immigration, nonprofits, immigrant, public policy, foundations, grants

*Corresponding author: Heath Brown, Department of Political Science, Seton Hall University, 400 South Orange Ave Jubilee Hall, 400 South Orange Ave, South Orange, NJ 07079, USA, E-mail: heath.brown@shu.edu

Polling in 2009 showed that a quarter of Americans believed that the nonprofit organization Association of Community Organizations for Reform Now (ACORN) "stole" the election for President Obama, including half of those whom had voted for Senator John McCain. Four years later, the same percentage of Republican voters believed ACORN had again stolen the election for the President, despite ACORN having been closed in 2010 (Smith 2010).

Accusations of an ACORN-led conspiracy to steal the 2008 or 2012 elections, though, were both unsubstantiated. A large body of evidence collected by nonpartisan sources suggested just the opposite: ACORN rarely violated the law, particularly as their activities related to registering voters, and coordinated voter fraud occurs very infrequently. ${ }^{1}$ But conspiracy theories aside, there were

1 To read the full Judiciary Committee report, see: http://judiciary.house.gov/hearings/pdf/ CRS-ACORN091222.pdf. 
coordinated, national efforts to mobilize voters and to overcome the closing of ACORN. Knowing that first- and second-generation immigrants have tended to vote at much lower rates than other groups of voters, starting in the early 2000s, foundations spent hundreds of millions of dollars to support the non-partisan work of thousands of nonprofit organizations to register, educate, and mobilize voters, especially eligible immigrants. During the same period, emboldened by the successful closing of ACORN and rise of the Tea Party, millions of dollars were also spent to support advocacy to change voting laws and state immigration regulations, perceived by some as aimed to intimidate immigrants and suppress them from voting.

To understand these competing and parallel efforts, it is first necessary to examine the ways foundations have historically been involved in the public policy process through their support for the operations of nonprofit organizations, then to show how foundations, on both the Left and the Right, have prioritized the issue of immigrants and immigration as a national funding priority since the early 2000s. The article demonstrates the patterns and structure of grant making over the last decade for immigrant issues so as to better contextualize the 2012 election and the role nonprofit organizations have increasingly played in electoral politics around immigration. These are important and timely issues, because the size of the first- and second-generation immigration population in the US continues to grow, and immigration reform remains a prominent issue for federal, state, and local policy makers.

In this article, I employ an eclectic, mixed method combing aspects of institutional historical analysis, secondary data analysis, and elite interviews. The result is a paper that is exploratory and investigative, but also one anchored in scholarship on the key issues.

\section{Historic role of philanthropic foundations and the policy process}

In the last 100 years, the increasingly important role of private philanthropic foundation cannot be underestimated, and their role in the movement to register and mobilize immigrant voters has been prominent. The ascension of foundations in American policy making was facilitated by changes in federal laws in the late 1960s which led to rapid growth in foundation giving (Ferris and Harmssen 2009). In terms of sheer numbers, foundations have ballooned, increasing threefold from 21,887 in 1975 to 76,610 in 2010. Foundations have also grown, because their invested assets have expanded rapidly from growth in 
the stock market, and the amount they give out each year increased because of new mandates from Congress. According to Roelofs (2003), starting in 1969, Congress required private foundations to give out $6 \%$ of their earnings on invested assets each year. This was later amended in 1981 to 5\%. Thus, in 2010 , the $\$ 75$ trillion in foundation assets resulted in the awarding of $\$ 45$ billion in various types of grants, more than the total budget for the National Science Foundation ( $\sim 7$ billion) and National Institutes of Health ( $\$ 30$ billion) combined.

Though foundations are legally restricted by the IRS from lobbying or direct advocacy, they have long been associated with the policy process (Vaughan and Arsneault 2014). Anderson (2008) traced the work of Russell Sage Foundation back to the turn of the previous century and that Foundation's interest in the financial services sector. Concerned with unscrupulous banks and banking practices, Russell Sage helped develop new ideas for reforming pubic policies on lending. These ideas, and others, put Russell Sage at the forefront of the Progressive Era reforms of numerous US political institutions.

Russell Sage was not alone. Many scholars have theorized about the role that foundations play in debates about policy ideas or what John Kingdon (1995) famously called the "policy stream." Foundations often act as "policy entrepreneurs", linking funding, ideas, and people together (Mintrom 2000). For example, Weidenbaum (2009) found that some prominent think tanks - often the home to policy entrepreneurs - receive more than a quarter of their revenues from foundation grants.

Foundations are most prominently involved in influencing key policy issues through financial support for the formation and operations of nonprofit organizations (Mandeville 2007; Sandfort 2008). In The New Liberalism, Jeffrey Berry's (1999) seminal account of the rise of citizen groups, he wrote: "For the development of citizen groups, however, the most important reform effort was initiated by the Ford Foundation... The Foundation supported a cadre of sixteen public interest law firms whose avowed intention was to broaden representation before government and to open up the governmental process” (p. 26). Other foundations have followed this model and supported policy and advocacy work in a variety of policy areas. According to Rhodes (2012), the Ford Foundation and Carnegie Corporation, among others, were instrumental in funding aspects of the educational reform movement during the 1990s, and the Gates Foundation stands above all others in providing funds for nonprofits working on educational issues in the 2000s (Reckhow 2012). In her recent account of education reform, Reckhow wrote: "Major foundations, such as the Gates Foundation, Broad Foundation, Carnegie Corporation, and Walton Family Foundation, have financed the development of a new organizational 
infrastructure in education policy... Without private funding, many of these organizations would not exist” (p. 3). Weissert and Knott (1995) linked three foundations (The Robert Wood Johnson Foundation, the W.K. Kellogg Foundation, and The Pew Charitable Trusts) to health policy making, and Bob (2012) showed how foundations with Left- and Right-leaning ideologies were involved at the global-level on funding groups on either side of gay rights and gun policy debates. Finally, Teles (2009) tied development of the conservative legal movement of the 1980 s and 1990s to the funding of student organizations at law schools from the Olin Foundation.

Despite well-known inequities in political participation and other sociopolitical outcomes for immigrants, immigrant-serving nonprofits have not always been the beneficiaries of such generous foundation support (Ecklund 2005; Uhlaner et al. 1989). Ramakrishnan and Viramontes (2006) examined civic organizations across California and found that "ethnic" organizations were more likely than "mainstream" organization to provide religious services or a multitude of social services, whereas "mainstream" were more likely to provide education, sports, and health services. But when it came to advocacy organizations serving ethnic groups in particular, the authors explained that they are "the most resource-poor, often depending on the time and monetary contributions of a handful of individuals” (p. 76). Evidence has also demonstrated that immigrant-serving nonprofit organizations in San Francisco have been severely underfunded, in part, because "immigrants are not seen as sufficiently legitimate interlocutors and civic partners" (de Graauw et al. 2012, 2). Other research on California suggested that, in proportion to their share of the local population, there was an under-representation of nonprofit organizations that serve immigrants, though the extent of the inequity may be exaggerated by official undercounting (Gleeson and Bloemraad 2012). And findings from other parts of the country confirm similar inequities found in California. de Leon et al. (2009) analyzed the Washington, DC-metro area and the universe of community-based organizations in Virginia, Maryland, and the District of Columbia. They found that there were 533 immigrant-serving nonprofits in the region and that their numbers were growing, driven by recent increases in immigration. The study reinforced the earlier finding about type of service: religious-oriented organizations predominated and, with the exception of Latino organizations, there were relatively few advocacy-oriented organizations, despite the proximity to the nation's capital. The authors found that the longer history of political participation of Latino immigrants in the Washington, DC region, and their large numbers, means Latino groups are much more politically oriented than Asian and African groups, which lack the institutional history and political contacts to easily lobby policy makers. 
Thus, the last 50 years have seen foundations' move to the center of important policy debates, aided by new regulations and various opportunities to form common cause with nonprofit grantees. Over the last decade, as awareness grew of the demographic shifts occurring in the country and of the low rates of political participation among immigrants, foundations increasingly sought a role in immigration policy. Foundations have looked to immigrantserving nonprofits, most unable to support politically-related work on their own, to help better integrate newcomers, and a substantial amount of their support has been given to immigrant-serving nonprofits to register, educate, and mobilize new voters.

\section{The changing structure of funding for immigrant issues and immigrant-serving nonprofits}

In order to focus their influence, foundations concentrate their giving on certain policy sectors. In 2010, the Foundation Center estimated that education $(23.7 \%$ of total foundation funding), health (21.7\%), and human services (15.1\%) were the three policy areas that received the largest portions of funding. ${ }^{2}$ Public affairs, the broad policy area where most funding is provided on immigrant issues, made up $12.3 \%$ of the foundation funding in 2010. Within that policy area, foundations provided various nonprofits more than $\$ 2$ billion for projects related to ethnic and racial minorities and \$265 million for projects focused on immigrants and refugee issues. These levels are historic highs for grants related to immigrants. Indicative of this, the trend of funding for immigrant issues has been sharply upward since 2000 (see Figure 1): foundation grants increased for immigrants and refugee issues, doubling in under a decade from less than $\$ 150$ million to a peak of more than $\$ 300$ million in 2008. The reasons for this spike in 2008 are likely related to the precarious position of immigrants after September 11, the national attention drawn to immigration following the 2006 rallies in many US cities, and the on-going discussion of immigration reform that intersected with a presidential election.

2 Throughout the article, data on foundation grants are drawn from publicly-available information from the Foundation Center at http://foundationcenter.org/findfunders/statistics/, annual IRS tax documents available at http://Guidestar.org, or information published by each foundation. 


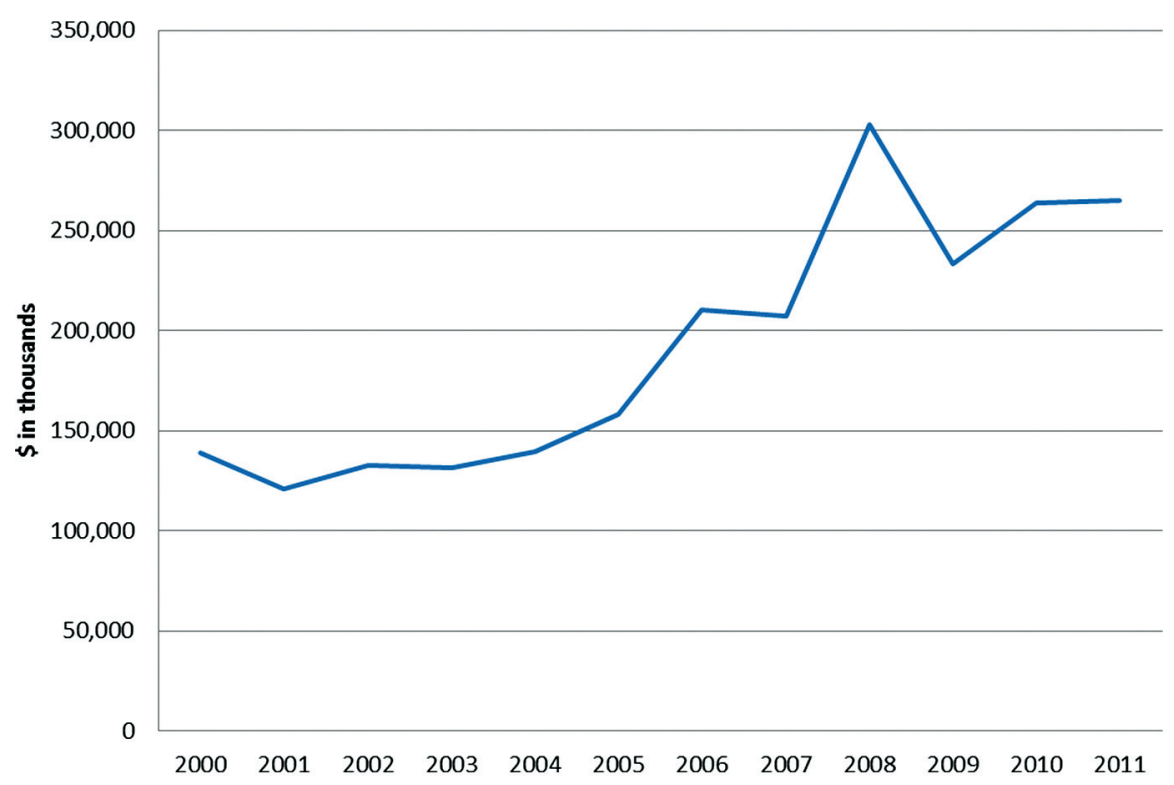

Figure 1: Total foundation dollars for immigrant and refugee grants, 2000-2011

Source: Foundation Center, see: http://foundationcenter.org/findfunders/statistics/

There is also a geographic dimension to foundation giving related to immigrants. Immigrants reside in all parts of the country, but are most numerous in the West and Northeast, and least in the Midwest. California, New York, and Texas are the three largest states in terms of the number of foreign born, not including those residing with an undocumented status. ${ }^{3}$ Foundations reflect these patterns to some extent. In 2011, more than $40 \%$ of donations went to organizations and projects based in the Northeast, followed by West, Midwest, and the South (See Figure 2). These patterns have remained relatively unchanged since 2007, though in 2008 there was a shift in emphasis to projects in states in the West, which mirrors the growth in immigration primarily from Mexico into Texas, Arizona, and California.

But to understand the full structure of funding for immigrant-serving nonprofits, traditional, private philanthropic foundations have to be conceived of in the context of other, new philanthropic organizations. There were numerous individual foundations and collaborations among foundations that provided grant opportunities in 2012 to immigrant-serving nonprofits to do voting-related

3 Based on data for 2011 from the Migration Policy Institute: http://www.migrationinformation. org/datahub/acscensus.cfm\#rankings. 


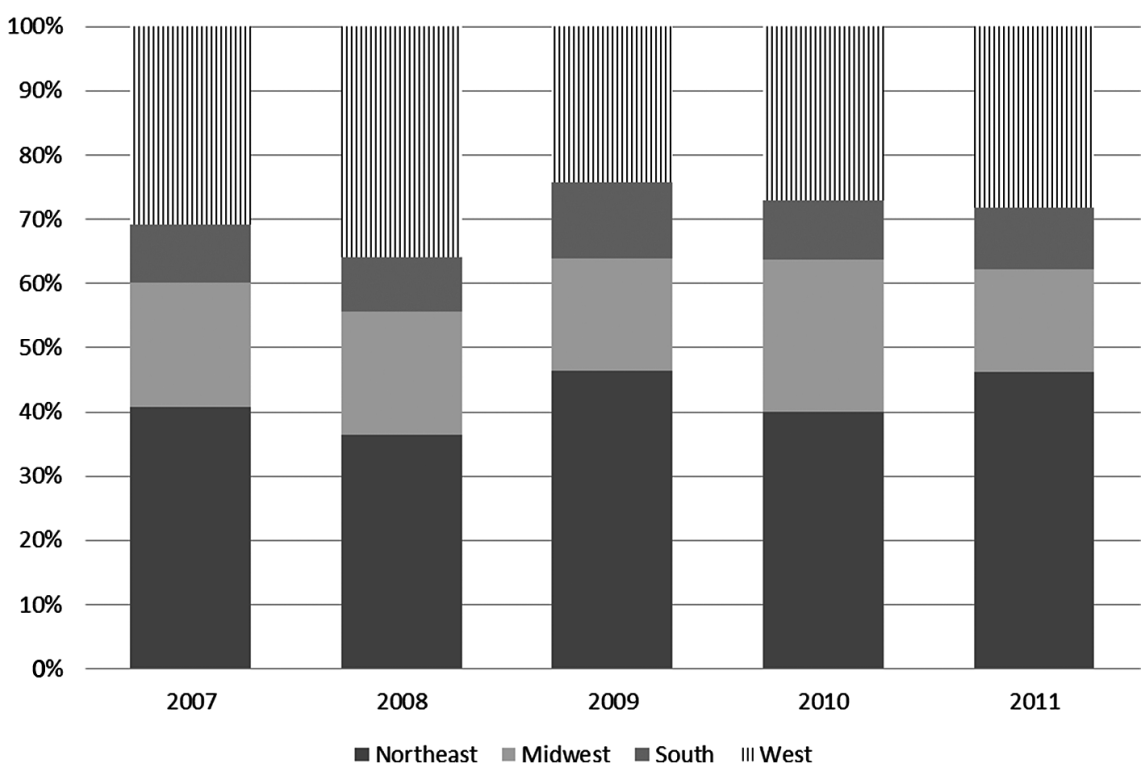

Figure 2: Distribution of foundation grants by region 2007-2011

Source: Foundation Center, see: http://foundationcenter.org/findfunders/statistics/

work. ${ }^{4}$ Given these caveats, funding for these voting-related activities of immigrant-serving nonprofits comes through a "Russian nesting-doll" arrangement of inter-linked organizations and streams of funding. Understanding this complex structure can help make better sense of the immigrant voter movement. At the outer-shell, several well-known foundations (National Foundations) provided large, multi-million dollar grants to make possible much of the work of new

4 It is worth noting that while the focus of this article is on voting and electoral activities (registering new voters, translating voting information, holding candidate forums, etc.), many grants are provided to expand or enhance the more general "civic" or "public participation" activities of immigrant-serving nonprofits. It is exceedingly difficult to fully separate "voting" from "civic" or "public" participation, particularly during an election year. Throughout the article, I refer to "voter" participation and "voter" engagement activities, but acknowledge that some foundation support is neither given for such specific purposes nor spent exclusively on "voting" oriented projects. I also focus on nonprofit organizations that represent "immigrants." I use a loose definition of what constitutes an immigrant, which includes first-generation immigrants, those born in another country and naturalized in the US, but also second-generation immigrants who maintain many of the language, traditions, and interests of their immigrant parents. Some researchers (and official data reporting) treat second-generation immigrants as "ethnic minorities," but for the purpose of this study, which focuses on organizational activities, I deemed such an unnecessary distinction. 


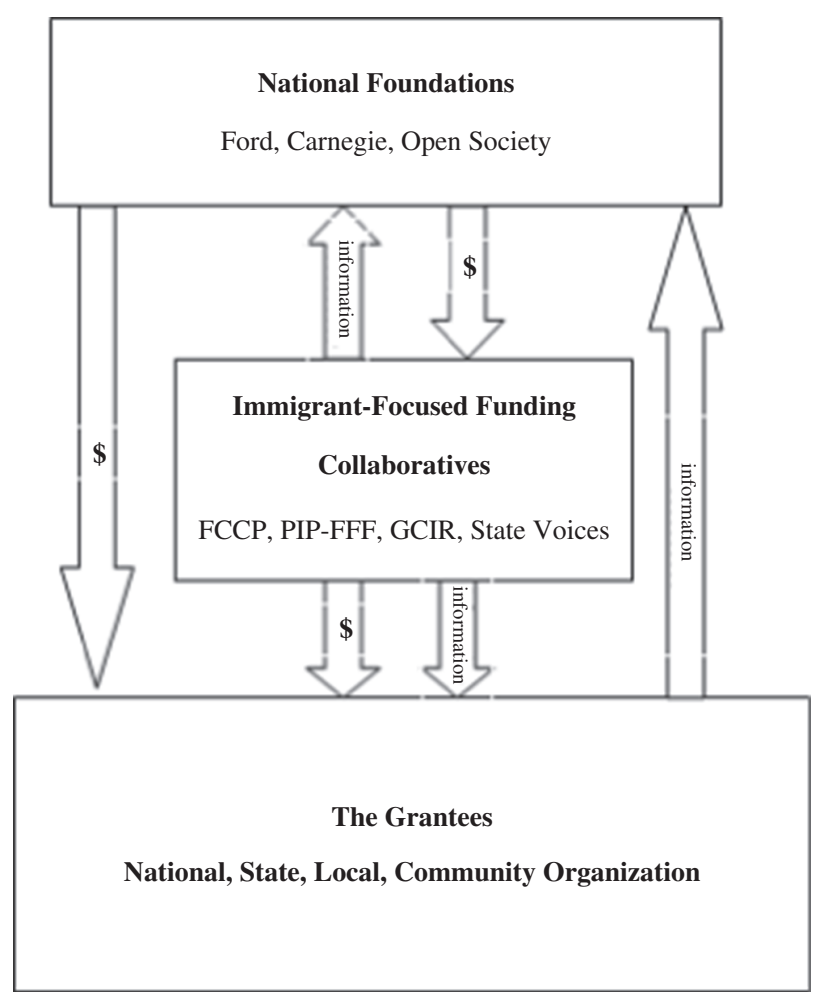

Figure 3: Schematic diagram of grant funding for immigrant issues

intermediaries (New Immigrant-Focused Collaboratives), which then gave smaller grants to local groups, often with budgets that total less than $\$ 100,000$ (Grantees). Money was not the only form of exchange between foundations and nonprofit organizations (see Figure 3). Information, technical expertise, and lessons learned were shared back-and-forth between each level of this complex structure of aid. The following unpacks and explains how these various organizations emerged and functioned in 2012. This section draws on secondary data from the Foundation Center and also elite interviews with foundation and immigrant-serving nonprofit leaders.

\section{National foundations}

Many major foundations have long prioritized issues of democracy and voter participation, but interest in these issues grew in the early 2000s. One factor that 
drove particular interest in immigrants and participation was the realization of the demographic changes that were reported in the 2000 and 2010 analysis of the decennial Census. Between 1990 and 2010, the number of immigrants living in the US ballooned, Hispanic Americans grew to a considerable portion of the US population, and Asian-Americans were the fastest growing. But other events also affected the decisions foundations made. September 11, 2001 had ramifications that went beyond a new awareness of global terrorism threats. The perception that the threats had ethnic and religious dimensions resulted in immediate concerns for immigrants and ethnic minority groups. Hate crimes were directed at Arab, Muslim, and other Americans who were wrongly linked to the terrorist bombings in New York City and Washington, DC, often just based on their dress or physical appearance. Foundations were keen to address this issue. Hasan Jaber, the executive director of Arab Community Center for Economic and Social Services (ACCESS) - a Dearborn, MI-based Arab-American nonprofit - recalled that "the one [foundation] that took interest first was Ford Foundation after September 11th, [they were] the ones who approached us and said we need to do something on civic engagement." 5

The Ford Foundation is one of the oldest and largest private philanthropic foundations, with assets of more than $\$ 10$ billion. The foundation has defined the immigrant problem in the following way:

A greater influx of immigrants has come to the United States in the past 25 years than at any time in history, engendering a backlash that has stripped large segments of the immigrant community of their rights. This population confronts large-scale immigration roundups, the denial of due process in deportation proceedings, abusive detention conditions, and increased hate crimes and bias attacks.

In line with that framing of the issue, Ford's interest in immigrant issues was reflected in 2011-2012 with major grants to the Asian-American Legal Defense and Education Fund (\$100,000), the National Council of La Raza (\$1.8 million), and Voto Latino $(\$ 750,000){ }^{6}$ These individual grants made up a small portion of the foundation's total giving, but were an indication of their strong interests in the issue.

Ford has long worked in close partnership with another venerable foundation, the Carnegie Corporation of New York. Carnegie had been interested in voting issues since the 1990s, at that time focused on campaign finance debates

5 Based on interview with Hasan Jaber, February 25, 2013.

6 For the full database of Ford Foundation grants, see: http://www.fordfoundation.org/grants/ search. 
waging in Washington and many state capitals. Just a year before September 11, the 2000 Supreme Court decision in Bush v. Gore exposed deep weaknesses in US election law and voting procedures. In part of a response, Carnegie gave numerous grants to organizations working on election technology and implementing reforms to state education procedures, particularly those related to disenfranchisement of groups of voters. ${ }^{7}$

During the 2000s, Carnegie added a new focus on immigrant integration and voter participation. According to the foundation's 2004-2005 annual report: “A relatively new emphasis of the Strengthening US Democracy program is immigrant civic integration. A network of national and local organizations serving immigrants has received support to provide legal assistance and advice about naturalization" (p. 5). ${ }^{8}$ But Carnegie's agenda neither was narrowly focused on a handful of grants nor was solitary; it had ambitious aims related to immigration and immigrants. Geri Mannion, who has led many of these efforts, elaborated the approach in a 2008 publication:

But [an immigrant's] ability to fully integrate into our society is being challenged by an immigration system that is clearly broken. In collaboration with donor partners such as the Ford and Horace Hagedorn foundations, Atlantic Philanthropies and the Open Society Institute, the corporation's goal is to work with its grantees and support their collaborative efforts to integrate immigrants so that all of America can continue to benefit from the skills, ideas and dreams of its newest citizens. ${ }^{9}$

These far-reaching objectives have been reflected in grant data. Based on information from the Foundation Center, starting in 2007, there was a sharp increase in funding for this area, totaling more than \$14 million in 2012 (See Figure 4). Major grants were given by Carnegie to the Public Interest Projects in 2008 (a grant for \$6 million and another for \$6.5 million), in 2011 (a grant for \$3 million and another for \$5 million), and then in 2012 (a grant for \$5 million). In 2012, Carnegie also gave large grants to the Immigrant Legal Resource Center ( $\$ 5$ million), America's Voice Education Fund (\$1.5 million), and Center for Community Change (\$1 million), all dedicated to immigrant integration and voter work.

7 For the full Carnegie annual report, see: http://carnegie.org/fileadmin/Media/Publications/ PDF/carnegie_review_fall_2009.pdf.

8 For the full Carnegie annual report, see: http://carnegie.org/fileadmin/Media/About/ annual_report/CCNY_04-05_annual.10.pdf.

9 For the full Carnegie report, see: http://carnegie.org/publications/carnegie-reporter/single/ view/article/item/69/. 


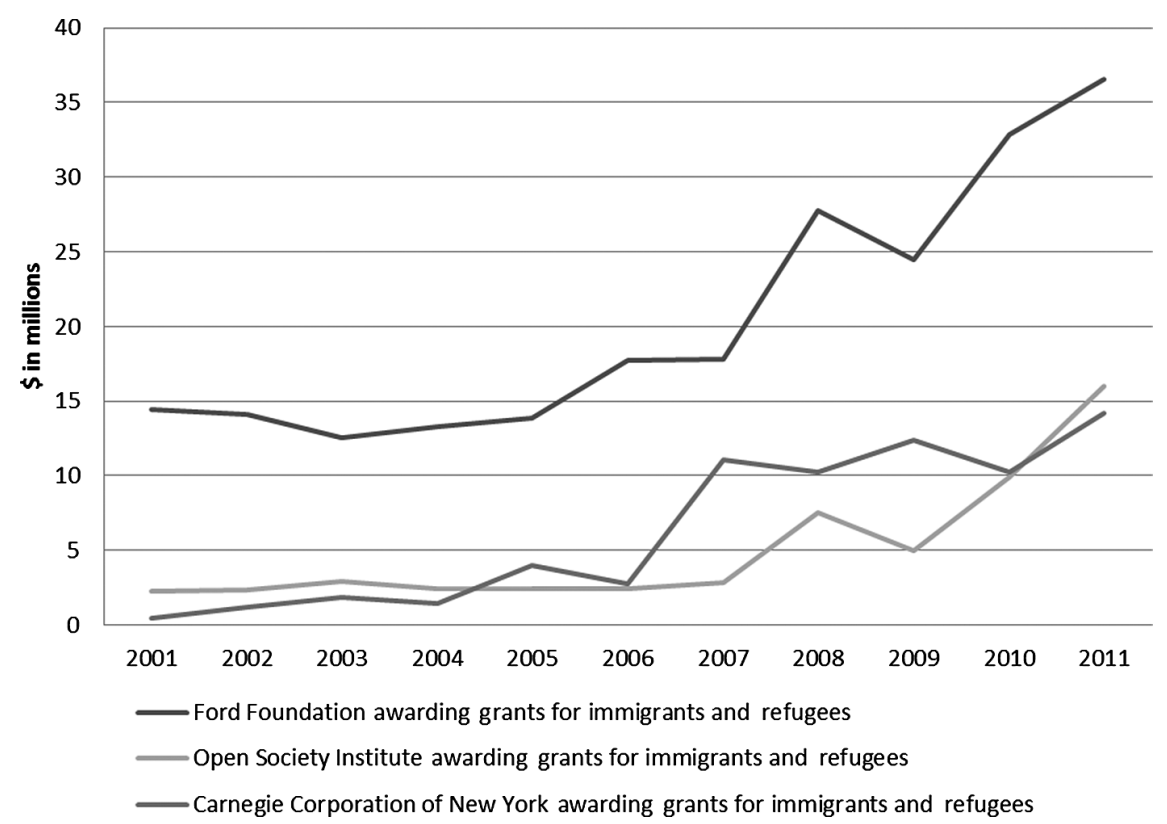

Figure 4: Total giving for immigrants and refugees from Ford Foundation, Opening Society Institute, Carnegie Corporation of New York, 2001-2011

Source: Foundation Center, see: http://foundationcenter.org/findfunders/statistics/

\section{Immigrant-focused collaboratives}

Ford and Carnegie, along with the Open Society Foundations, the Knight Foundation, Unbound Philanthropy, and others, each individually prioritized immigrants, voting, and civic engagement during the 2000s, but they also did so in partnership or what Reckhow (2012) called "convergent grant making." One effort to better bind the various independent foundation efforts together in common cause was the formalization of a group called Funders Committee for Civic Participation (FCCP). The organization had been established in the 1970s, but not until the mid-2000s was a professional staff chosen. According to the executive director, Deb Ross, "a key aspect has been sharing funding strategies to increase the impact and avoid duplication." In addition to sharing information on election reform, ballot initiatives, and the census/redistricting, Ross explained that for the 200 foundations at the local, state, and national levels "immigrant civic engagement is a big issue, because we have a priority on equity issues."10 The Funders

10 Based on interview with Deb Ross, February 14, 2013. 
Committee pursues its mission primarily through convening member foundations for weekly phone calls and national meetings. The strategy has not been focused on distributing funds, but rather on distributing information.

Another collaborative that has bound the work of foundations together is Grantmakers Concerned with Immigrants (GCIR). Founded in 1990 by Mary McClymont, then employed by the Ford Foundation, GCIR aimed to help deal with the aftermath of the passage of the Immigration Reform and Control Act (IRCA) in 1986. They initially focused on the backlash against immigrants and implementation of welfare reform policies of President Bill Clinton. Today, GCIR is made up of more than 300 foundations and works "in the area of research, communications, programming, and technical assistance - as well as a large body of work on immigrant integration.” In line with the focus on integration, their work is increasingly tied to elections, and they publish major reports and hold meetings during election years.

Running parallel to FCCP and GCIR is another collaborative innovation that emerged out of this period of increased foundation focus on immigrants. The Four Freedoms Fund, a part of the Public Interest Projects (PIP also has separate "funds" that work on juvenile justice, low-income communities, human rights, and gender equity), was formed to address the need to collaborate on actual funding. These national foundations mentioned earlier

found they were hard pressed to serve the immigrant community whose most dire needs called for local action. Seeking effective new strategies to get needed money down to grassroots groups they couldn't reach, representatives of several large foundations got together to think through better ways to facilitate funding and move immigrant civic engagement and integration forward... Observing how small immigrant organizations regularly banded together to be more efficient and effective, [Michele Lord, then of the Ford Foundation] suggested starting a parallel funding collaborative on a national level. ${ }^{11}$

The initial grants were for \$2.8 million to create the Four Freedoms Fund, a reference to the famed Norman Rockwell painting based on the speech by President Franklin Roosevelt. According to the Fund: "The Four Freedoms Fund works by pooling large grants from individual foundations and making smaller grants to state and local immigrant advocacy organizations for strategic planning, board development, fundraising, policy analysis, organizing and media training” (p. 4). This approach, they argued, "simplifies the process of making a large number of grants to grassroots groups, while encouraging funder collaboration for strategic grantmaking” (p. 4).

11 For the full Carnegie report, see: http://carnegie.org/fileadmin/Media/Publications/PDF/carnegie_results_winter_08_rev.pdf (p. 3). 


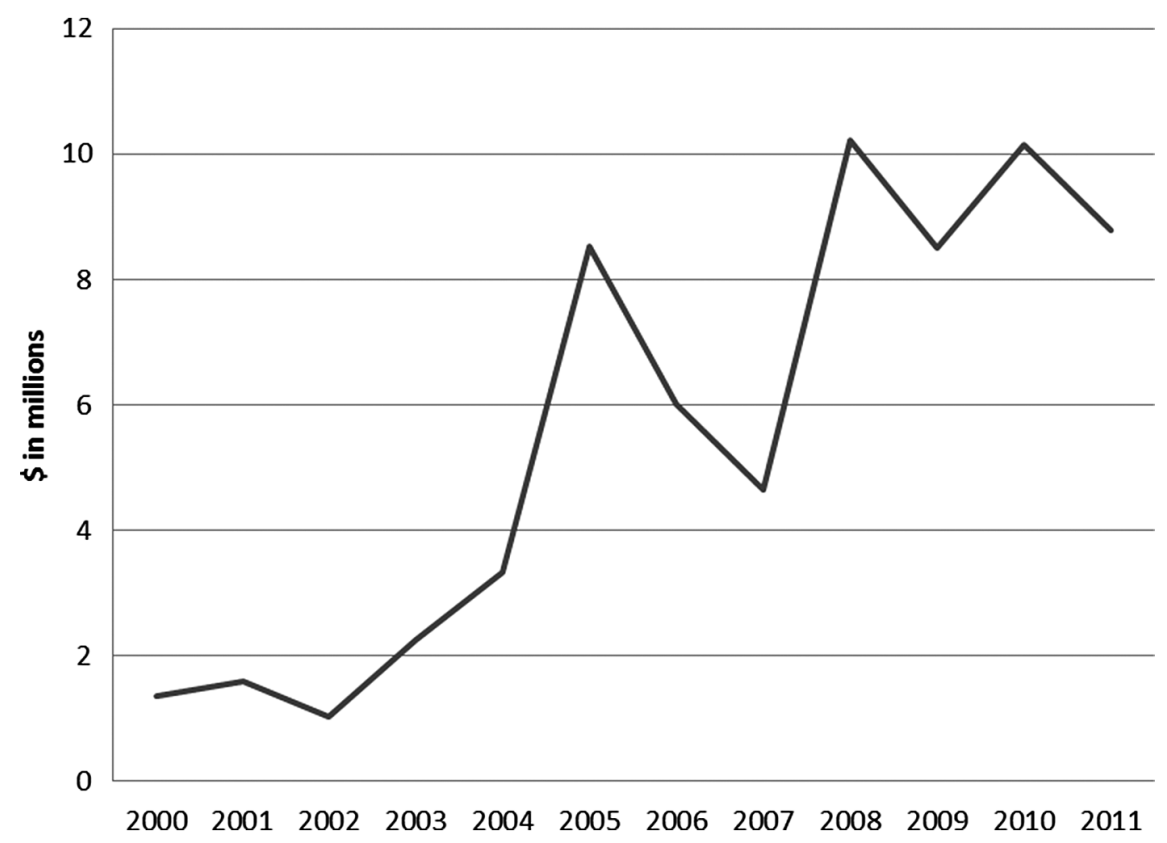

Figure 5: Grants to public interest project, 2000-2011

Source: Foundation Center, see: http://foundationcenter.org/findfunders/statistics/

Through the Public Interest Projects, the Four Freedoms Fund (referred henceforth as PIP-FFF) funded individual organizations and several electoral coalitions that then sub-granted to individual organizations. In Figure 5, one can see the rapid growth in Foundation grants to PIP-FFF starting in the mid-2000s. This figure also suggests an ebb-and-flow of funding PIP-FFF received from foundations based on election year: more was received in 2008 and 2010 than in offyear elections in 2007, 2009, and 2011 (data for 2012 and 2013 were not yet published when the research for this article was conducted). PIP-FFF used this foundation support to fund smaller organizations. Based on publicly-available IRS data for 2010, PIP-FFF provided large grants to South Asian-Americans Leading Together (SAALT) $(\$ 175,000)$, the New York Immigration Coalition $(\$ 225,000)$, and Latino Justice/PRLDEF $(\$ 150,000)$.

A final innovation during this time period was the formation of State Voices. State Voices was created in 2008 to work on civic and voter engagement and provide technological support to organizations, including those serving immigrants. In explaining their formation, State Voices wrote that the early founders "knew grassroots nonprofits could improve their effectiveness by working 
together, and they knew this sort of sophisticated collaboration would require a stable structure. The state table model was born."12 State Voices developed the "state table model" in order to have "a place where organizations could come together to share resources, community openly, build trust, engage in real field collaboration, and share their battles.” The organization started with tables in 11 states, but grew to 22 states linking 600 organizations by 2012. Each state table is overseen by a particular organization in the state: The Grassroots Institute of New Jersey for New Jersey, Blueprint NC for North Carolina, and Michigan Voice for Michigan.

State Voices received a portion of its revenue from foundations. PIP-FFF provided grants worth $\$ 400,000$ (2009) and $\$ 600,000$ (2011) to State Voices. State Voices, which also received a $\$ 1.5$ million grant directly from Atlantic Philanthropies and a $\$ 300,000$ grant from Ford, then gives out its own grants, typically less than $\$ 100,000$ to state and local groups such as: Ohio Voters Fund, Center for Nonprofit Voting, and Asian \& Pacific Islander American Vote.

State Voices had a unique strategy on voter engagement. They focused on technology, often giving access to electoral database and voter outreach tools. In particular, State Voices worked closely with Catalist, a private company that was created with seed money from George Soros (not funding by the Soros affiliated Open Society Foundations) by Laura Quinn and Harold Ickes in 2006. Catalist maintains a massive database of voter information, called the Voter Activation Network (VAN), which they rent to labor unions, political parties, and nonprofits such as State Voices. In states that do not have an established state table, State Voices established a "Tools for All Fund" in order to give technological support and access to the VAN to interested nonprofits.

\section{Grantees: immigrant-serving nonprofits}

Sitting at the center of the nesting-doll are individual nonprofit organizations or grantees. For an individual nonprofit, foundations are a valued source of funding for voter engagement, because other sources of funding - principally government grants - typically prohibit such political expenditures. Many of these nonprofits lack the slack resources from other sources, such as fees-for-services or donations, to add new political activities to their agenda. Foundations that are willing to support voter engagement, thus, are an attractive alternative.

12 For the full history of State Voices, see: http://www.statevoices.org/about-us/our-story/. 
Table 1: Top 15 recipients of foundation grants for immigrants and refugees, 2011

\begin{tabular}{cllrr}
\hline Rank & Recipient organization & State & Amount \$ & \# of grants \\
\hline 1 & International Rescue Committee & NY & $14,723,840$ & 69 \\
2 & Catholic Relief Services & MD & $13,189,757$ & 36 \\
3 & Public Interest Projects & NY & $8,470,000$ & 5 \\
4 & Immigrant Legal Resource Center & CA & $6,957,000$ & 22 \\
5 & InterAction: American Council for & DC & $6,332,599$ & 3 \\
& Action & & & \\
6 & Human Rights First & NY & $5,166,777$ & 21 \\
7 & Migration Policy Institute & DC & $4,998,000$ & 13 \\
8 & Asian-American Justice Center & DC & $4,550,000$ & 6 \\
9 & Friends of Yemin Order & MD & $3,801,060$ & 16 \\
10 & Asian Pacific American Legal Center of & CA & $3,670,000$ & 22 \\
& Southern California & & & 10 \\
11 & National Assoc. of Latino Elected and & CA & $3,566,761$ & \\
& Appointed Officials Educ. Fund & & & 13 \\
12 & Americas Voice Education Fund & DC & $3,285,000$ & 10 \\
13 & Latin American Youth Center & DC & $2,739,373$ & 5 \\
14 & National Immigration Law Center & CA & $2,730,000$ & \\
15 & National Immigration Forum & DC & $2,540,000$ & \\
\hline
\end{tabular}

It is difficult to fully disaggregate foundation grants for immigrant-serving nonprofit election work, because many grants are for multiple purposes and individual grants are not always publicly accessible, but Table 1 demonstrates which nonprofits were the largest recipients in 2011 across immigrant and refugee issues. These organizations ranged in purpose, a number focused on legal protections and civil rights (\#4 Immigrant Legal Resource Center and \#10 Asian Pacific American Legal Center of Southern California, and \#14 National Immigration Law Center), others focused more on refugee resettlement or immigrant services (\#1 International Rescue Committee and \#2 Catholic Relief Services). Much of the funding for voter engagement, as explained above, comes from Public Interest Projects (\#3) that redistributed the $\$ 8.47$ million in grants it received to smaller organizations.

Some of this funding went to non-electoral activities related to advancing immigrant rights, often through the courts or traditional policy advocacy. But other funding supported a range of voter engagement activities. Specifically, grants were used to hold public events such as voter registration drives and candidate forums. Funds also helped pay for new technology such as computers and software to remind voters to register and turn out to vote (Garcia Bedolla and Michelson 2012). And some organizations used funding to pay stipends to 
interns and volunteers to buttress existing staff in the months leading up to the election, to help translate voter information into other languages, and to canvas neighborhoods on Election Day. Any number of different nonprofit activities may be used independently or in tandem to increase voter engagement and draw attention to immigrant issues.

In spite of intermediaries such as PIP-FFF and State Voices, large foundations also provided funds directly to immigrant-serving organizations. For example, as noted earlier, ACCESS received early funding from the Ford Foundation, but in 2011-2012, in addition to grants from Carnegie, Ford, and the Open Society Institutes, it also received grants from PIP-FFF and State Voices. ${ }^{13}$ An affiliate of ACCESS, the National Network of Arab-American Communities (NNAAC) also received considerable grant support. According to their director, Nadia Tonova, "those [foundations] are our lifeline, not only for elections, but other work, without them we would not be able to function."14 NNAAC coordinates advocacy and civic engagement for ACCESS and also through 23 partner organizations across the country. NNAAC has even used foundation support to provide small grants $(\$ 2,000-\$ 3,000)$ to affiliated organizations to pursue voter engagement work. The funding is typically used to hold election-related events or provide small stipends for interns who may do neighborhood canvassing or get-out-the-vote (GOTV) work. This range of funders makes ACCESS and NNAAC unique and their voter engagement portfolio as deep and broad as nearly any other in the country.

The experience of the Consortium of Hispanic Agencies, based in Detroit, MI, is also indicative of the complex ways foundations interact with grantees around voter engagement. The Consortium linked together six local agencies. ${ }^{15}$ The Consortium had loosely tied the work of these agencies together since the 1970s, but even after a new policy agenda was agreed upon in the 1990s, advocacy work was ineffective. Executive Director Norman Bent summarized the dilemma that "individually they could not do advocacy, after the 1990s agenda was drafted it created momentum, but died down over ten years." In response, the organizations collectively asked: "how do we strategize? how do we focus?” The Consortium began by establishing committees around different important issues, but they soon realized “we can’t focus on all nine issues, how

13 For the full ACCESS annual report, see: http://www.accesscommunity.org/site/DocServer/ ACCESS_2011_Annual_Report_FINAL_web.pdf?docID $=4961$.

14 Based on interview with Nadia Tonova March 26, 2013.

15 Community and Health Social Services (CHASS), Detroit Hispanic Development Corporation (DHDC), Latin Americans for Social and Economic Development (LA SED), Latino Family Services (LFS), Mana De Metro Detroit, and SER Metro Detroit. 
do we prioritize?" Initial advocacy was aided by foundations: "Skillman Foundation was the first, then Kellogg, and minor dollars from NCLR (National Council of La Raza).” In January 2012, the Consortium received a four-year \$1 million grant from the Kellogg Foundation to "build the necessary infrastructure to strengthen collaborations and implement a Latino Agenda for Southwest Detroit." 16

But the collective organizations understood that politics was more than just advocacy, voting and elections mattered too. Bent recalled: "so when we realized, how do we get involved in civic engagement? [our county in Michigan] was one of the only counties that grew in the 2010 census ... a very high number of eligible individuals, but only a small percent participated." The groups believed that they "had to change that, had to work on leadership development, get representation in governance, and build a pipeline ... we felt that we had to get involved in the election piece."

But the group also knew that since "existing funds were for organizing," there was no external support for their plans to expand civic engagement: "Kellogg has been open to voter mobilization piece, however the funds were already allocated for other things." Fortunately, there were other options: "State Voices came in handy ...[its] role was to provide that funding” with matching funds from the NCLR. "State Voices funds provided money to hire part-time coordinator, to hire students to go door-to-door." They used those new foundation dollars to hire nearly 80 student volunteers during the summer to canvas neighborhoods door-by-door.

This history of overlapping and complementary foundation funding allowed for a wide array of new activities to expand what the Consortium could accomplish. It is unlikely that this would be possible without the coordinating work of collaboratives such as GCIR, FFF-PIP, and State Voices. In other parts of the country, similar events have transpired. In Arizona, Leticia De La Vara explained that following the passage of anti-immigrant state policies, "Funders came forward to ask for the coalition." Through a coalition approach called One Arizona, the expense of certain aspects of voter engagement - such as data management software - could be shared, and efficiencies gained across organizations. De La Vara continued that "unified branding under certain Latinospecific" messages and "combined funding efforts for television, news, and radio" were gained by creating a new coalition.

16 For the full announcement from the Consortium, see: http://chadetroit.org/assets/ Consortium\%20of\%20Hispanic\%20Agencies_WKKF\%20grant\%20announcement\%20011212\% 20FINAL.pdf. 
ACCESS, the Consortium, and One Arizona were indicative of the recent experience of a group of grantees, each able to fund new or enhanced electoral activities related to the people they serve. These grantees shared a priority with major private foundations, and received considerable financial support accordingly. Foundations provided funding, of course, but the other aspects of their influence cannot be underestimated. Their ability to reach across community and state boundaries, to link various groups together, and to leverage the expertise gained from previous grant making can also greatly direct and change social action, yet cannot be easily monetized. Increasing rates of political participation by immigrants also must be attributed in part to this complex structure of funding.

But the beneficiaries of the convergence of grant making for immigrantserving organizations also reflect other recent foundation preferences. All three of the organizations described above are pan-ethnic organizations, merging the interests of Arab-Americans or Hispanic Americans across ethnic boundaries. Of the top 50 grantees in 2011 (See Table 1), all reflect a pan-ethnic - AsianAmerican Justice Center and National Association of Latino Elected and Appointed Officials Fund - or pan-immigrant orientation - National Immigration Forum and Immigrant Legal Resource Center. There are obvious reasons for these preferences: pan-ethnic organizations may have a wider base of constituents, because they do not represent just a single ethnic group. And these pan-ethnic organizations also fit with the principle of collaboration that foundations have used to focus their own giving. However, pan-ethnic identify is a social construction that many immigrants reject. The Pew Hispanic Center, for example, found that a majority of Hispanic Americans (51\%) prefer to identify themselves by their family's country-of-origin. Just a quarter (24\%) of those polled identified themselves using the pan-ethnic title of "Hispanic American" or "Latino American". Cristina Beltran (2010) referred to this as Latinidad: a dubious social construction supported by Latino leaders in order to gain power in numbers and resulting political influence. Similarly, within the Asian-American community, the majority of individuals (69\%) do not describe themselves with the pan "Asian-American” moniker. Because many immigrants ally with their country-of-origin background they affiliate with at least some organization that shares this view. To suggest that these nonprofits all pursue a common immigrant agenda or view immigration issues alike would be a great imposition on their independence and autonomy.

And these preferences were not always so strong. In 1998, though panethnic nonprofits won many large grants, the Jewish Fund for Justice, Chinatown Action for Progress, National Coalition for Haitian Rights, Mexican American Legal Defense and Education Fund were also in the top 50 of grant 
recipients in the category of immigrant and refugees. Yet relatively few of these ethnic-specific nonprofits have benefited from the recent expansion and convergence of grant making. Nonprofits that represent Indian Americans, Chinese Americans, or Egyptian Americans, despite the considerable size of each population, have been largely shut out of the opportunity to expand their voter engagement activities through grants. In some cases, these ethnic-specific groups may link to pan-ethnic coalitions that receive foundation support through a state or local immigrant coalition, and then receive some aid. But are they compelled to acquiesce to the priority that foundations place on the pan-ethnic perspective? In order to receive support, must they choose between the ethnic identify held by many of their constituents and the potentially conflicting view of ethnicity held by national foundations? In other policy areas, foundations have been criticized for their overwhelming influence. Reckhow (2012) described how the Gates Foundation and a handful of other funders have dominated education reforms in the 2000s. Gates' financial largesse has crowded out alternative ideas and isolated nonprofits that are not sympathetic to the foundation's point of view. The evidence presented above on which types of immigrant-serving nonprofits have been preferred by foundations raises similar concerns about how open the field of immigrant integration is to unconventional perspectives and approaches.

\section{Funding perceived to be hostile to immigrants}

The prominent efforts described above to support immigrant-serving nonprofit organizations occurred alongside, and were likely propelled by, giving on other issues, some potentially hostile to the interests of immigrants. Little evidence suggests the focus of this giving was to expand voter registration and turnout. Rather, the work by nonprofits aimed to strengthen voting laws and reduce voter fraud - often called Voter ID laws - was initiated and supported by a different array of philanthropic foundations and equally novel financial intermediaries. Some of the leading foundations supporting this policy development were the same foundations. Thomas Dye (2000) categorized as “conservative": the Lynde and Harry Bradley Foundation, the Sarah Scaife Foundation, and the John M. Olin Foundation. The Koch family foundations, a group of foundations supported by various family members of Fred Koch, also played a major part.

To be sure, the major political phenomenon of the 2008-2012 time period was the rise of the Tea Party or, more aptly, Tea Parties. According to Skocpol and Williamson (2013), in the wake of the 2008 election, individuals established 
over 900 Tea Party organizations across the country. Propelled by talk radio and supported by the political nonprofit FreedomWorks and several private foundations, many, though not all, Tea Party organizations were either ideologically conservative or libertarian, hostile to the federal government, and largely opposed to immigrants and immigration (Williamson and Skocopol 2011; Disch 2012). Tea Party organizations were actively engaged in efforts to elect antiimmigration candidates at the state and national level and pursued policy change to tighten border control, to limit illegal immigration enforcement, and other measures viewed as antagonistic to immigrants such as Voter ID laws. Postel (2012) argued that "Tea Party influence in more than a dozen states has resulted in legislation to rescind motor voter laws, expand felony disqualification lists, add new residency and identification requirements, and impose other hurdles that make it more difficult to vote" (p. 36).

But Tea Party advocates pushed beyond bureaucratic changes in voting laws. Some Tea Party groups relied upon the racialized language that has dominated debates about immigration used in previous elections (Mcllwain and Caliendo 2012). For example, the Texas-based 1,776 Tea Party was, according to Devin Burghart (2012), "the national faction most directly connected to the anti-immigrant movement” (p. 72). The most radical among the Tea Party groups opposed what they called "anchor babies" and advocated for changes in the Fourteenth Amendment of the Constitution to eliminate the practice of birthright citizenship, thereby putting an end to the long-standing legal practice of granting citizenship to all those born in the country (Postel 2012). And these antiimmigrant views were reflected to some extent in beliefs of the rank-and-file membership of Tea Party organizations. Parker and Barreto (2013) found through public opinion research that among the most stridently affiliated with the Tea Party (true believers), a majority believed that new immigrants increased crime (55\%), and new immigrants were too powerful (54\%). A majority also believed birthright citizenship should be repealed (56\%) and that the DREAM Act should not be passed (54\%). These figures, though in line with the agenda of many Tea Party organizations, are hardly a consensus opinion, and those more weakly affiliated with the Tea Party (who Parker and Barreto call "true skeptics") were less supportive of anti-immigrant beliefs. Despite these complex sentiments among Tea Party supporters, in the run-up to the 2012 election, organized antiimmigrant advocacy often ran parallel to and was abetted by advocacy on behalf of Tea Party organizations and affiliated campaigns.

Some national foundations, though, have viewed immigration in a more nuanced fashion, often aligned with the more traditionally conservative, probusiness view of immigration as associated with trade and economic growth. Many of these foundations conceptualized civic participation in different ways 
as well. Indicative of this mixed view of immigration was the Bradley Foundation. The Bradley Foundation described its programmatic interests in 2012 as aiming "to encourage projects that focus on cultivating a renewed, healthier, and more vigorous sense of citizenship among the American people, and among peoples of other nations, as well" and explained further that "It is important to note that our view of citizenship is not primarily concerned with promoting civics education, voter awareness or turnout, or similar activities narrowly focused on voting and elections." Bradley's view of citizenship did not directly mention immigrants, but the allusions to voter turnout and elections could not be ignored. Moreover, Bradley supported immigrant and immigration nonprofits. In total, the foundation gave out \$31 million in 2011 to a variety of organizations and issues, including some focused on immigrant issues. Bradley provided grants in 2011 to the Latino Community Center $(\$ 75,000)$ and English Language Partners of Wisconsin $(\$ 35,000)$, and the Hispanic Free Market Network $(\$ 50,000)$.

But Bradley also gave funding to organizations that were perceived to be unsympathetic or outright hostile to immigrants. They provided a $\$ 35,000$ grant to True the Vote, the organization that was actively seeking to discredit signatures from voters used during the electoral recall of Governor Scott Walker in Wisconsin 2011. True the Vote was involved in other policy advocacy aimed to reduce voter fraud in Texas, Florida, and elsewhere (Skocpol and Williamson 2013). The grant from Bradley was ultimately rescinded after True the Vote was not given the necessary nonprofit status by the IRS. The Bradley Foundation also supported the American Legislative Exchange Council (ALEC) with grants totaling over \$200,000. ALEC was a think tank that developed policy recommendations and so-called "model legislation" that numerous states used to change voting laws.

Perhaps most suspiciously, and troubling to many, Bradley provided $\$ 10,000$ to the Einhorn Family Foundation to purchase billboards in Milwaukee that read "Voter Fraud is a Felony." Because the billboards were located in low-income neighborhoods and were posted anonymously by a "private family foundation", there was great concern about who was behind these efforts, and what their objectives were exactly (A similar billboard was placed by the Tea Party-affiliated group, Empower Massachusetts (Skocpol and Williamson 2013)). Many interpreted these billboards as a form of voter intimidation. A local newspaper later discovered that Einhorn was behind the purchase and that the Bradley Foundation grant was the source of their funding. To be clear, it is certain neither whether Bradley Foundation officials knew in advance about the billboard nor whether they supported the message the billboard promoted, but the connection raised concerns. 
The Sarah Saife Foundation, one of a number of foundations overseen by Richard Mellon Scaife, also has been involved in immigration issues. Scaife gave out \$15 million in grants in 2011 and used a portion of those grants to support immigration policy research organizations. Specifically, Scaife provided a $\$ 125,000$ grant to the Center for Immigration Studies, a research think tank. The Center claimed that:

The data collected by the Center during the past quarter-century has led many of our researchers to conclude that current, high levels of immigration are making it harder to achieve such important national objectives as better public schools, a cleaner environment, homeland security, and a living wage for every native-born and immigrant worker. ${ }^{17}$

The Center made it clear, though, that

These data may support criticism of US immigration policies, but they do not justify ill feelings toward our immigrant community. In fact, many of us at the Center are animated by a 'low-immigration, pro-immigrant' vision of an America that admits fewer immigrants but affords a warmer welcome for those who are admitted.

The Center also received substantial funding from the Scaife Family-affiliated Colcom Foundation (over \$20 million in 2010 and 2011 alone) and smaller gifts from Bradley $(\$ 25,000)$.

Scaife was a consistent funder of the National Center for Public Policy Research (NCPPR) ( \$100,000 between 2007 and 2011). In the 1990s, the Bradley Foundation was also a big supporter of the NCPRR, as was the Carthage Foundation and Randolph Foundation. In the spring of 2012, the NCPRR announced that they would create a New Voter Identification Task Force after ALEC decided to stop pursuing Voter ID policies. NCPRR took up leadership on efforts to convince state legislators to change election laws. ${ }^{18}$ These efforts had mixed effects on ultimate legislative outcomes, but the organization's role was significant and the funding it received was important to consider.

Though the funding infrastructure on the conservative side was less elaborate than for those funders supporting immigrant rights and voter participation, there are clear analogies between the two movements. The foundations on top of the structure have similarly long histories and broad based objectives to influence policy, though from decidedly different ideological vantage points. And each used intermediaries to help funnel money to the grassroots of the policy process. In the case of these conservative foundations and philanthropists, FreedomWorks served a similar role as PIP-FFF, GCIR, and FCCP combined.

17 To see the full description, see the CIS website: http://www.cis.org/About.

18 To read the full press-release, see: http://www.nationalcenter.org/PR-VoterID_041812.html. 
Though FreedomWorks operated mainly with non-tax deductible private donations as a 501(c)(4) nonprofit, rather than establishing itself as a 501(c)(3) philanthropic foundation, it ultimately provided many of the same financial and non-financial links between philanthropists and organizations that were directly engaged in advocacy and electioneering. As their mission statement declared: "FreedomWorks recruits, educates, trains and mobilizes millions of volunteer activists to fight for less government, lower taxes, and more freedom." They pursued their mission in support of these non-partisan issues, but FreedomWorks also engaged more directly in campaign donations than PIPFFF and the other intermediaries mentioned earlier. According to OpenSecrets. org, FreedomWorks had nearly \$20 million in unregulated outside spending and $\$ 2$ million in regulated campaign donations through its associated Political Action Committee, FreedomWorks for America. To be sure, FreedomWorks was overseen by former Republican House Majority Leader Dick Armey and most of its donations and campaign spending directly or indirectly supported Republican and Tea Party-affiliated candidates for office. The more explicitly partisan and aggressively political approach of FreedomWorks made it different than those groups working to advance immigrant integration.

While total grants were meager compared to those given by Ford, Carnegie, and Open Foundations, and the overall infrastructure not nearly as organized, the impact of conservative foundations may have been just as powerful. According to the Brennan Center, between 2011 and 2012, 41 states debated proposed voter ID laws, and 19 states enacted some form of change associated with voter ID. These laws provided new barriers to voting and political hurdles for immigrant-serving nonprofits to confront in mobilizing their constituents in 2012 and beyond. But it is not just actual policy change that affected immigrant integration and voting. The funding of propaganda, billboards, and often fiercely anti-immigrant rhetoric greatly shaped the political environment into which immigrant-serving nonprofits worked in 2012. It may not have even been necessary to change every state law to require new forms of ID to vote or change when voting commenced and concluded. The atmosphere of 2012 was strongly influenced by the aggressively anti-immigrant voice of nonprofit groups and activists funded by foundations perceived to be hostile to immigrants.

\section{Discussion and conclusion}

In 2012, headlines celebrated the importance of Hispanic and Asian-American voters. In addition to historically high turnout from African Americans, a record 
11.2 million Hispanic Americans voted. Despite the closing of ACORN, other nonprofits, including the ones mentioned earlier, took on much of ACORN's legacy to hold voter registration drives, educate voters about key issues, and mobilize on Election Day through GOTV programs. Philanthropic foundations aided these successful voter engagement activities which resulted in almost no cases of voter fraud. But opponents of immigration and immigrants also scored electoral and policy victories. Voter ID laws and stricter immigration policies were passed in many states, leaving some groups of immigrants with greater hurdles to register and then ultimately turnout to vote. A different group of foundations and their intermediaries helped a different array of nonprofits pursue those aims.

But according to the Pew Hispanic Center, less than 50\% of eligible Hispanic and Asian-Americans voted, a far smaller portion compared to eligible African American and white voters (Lopez and Gonzalez-Barrera 2013). Would an even smaller portion have registered and then voted if certain foundations had not granted so much money to immigrant-serving nonprofit organizations? Or would a much larger portion have registered and then voted if the other set of foundations had not granted so much money to oppose immigration and impose new regulations on voting? No social science research has yet uncovered the causal relationships between these competing factors and what ultimately drove or impeded the electorate of newcomers and immigrants in 2012. Such research is needed as it would advance the work of nonprofit practitioners and scholars alike.

There is also no easy way to resolve these tensions between the enormous power of philanthropic foundations and independence of an individual immigrant-serving nonprofit organization. In so many cases, the interests of a foundation and a nonprofit align well, resulting in a successful and mutually beneficial grantor-grantee exchange. Many nonprofit leaders speak glowingly about the positive contribution foundations have made to immigrant rights, immigrant integration, and civic participation. But leaders who eschew funding opportunities out of deep concerns about what they sacrifice when they accept a grant or leaders who lack the resources to successfully respond to a request-forproposal, likely exist but are harder to identify. For these nonprofit organizations, lacking available foundation support, they may be increasingly compelled to turn to the community to support voter engagement work or risk failing to provide that service to constituents. Unfortunately, many communities lack the personal resources to support such requests.

As immigration policy rises on the agenda of Congress, many of the major problems facing immigrants may be ameliorated through comprehensive immigration reform. For nonprofits and foundations working to aid immigrants, this is a positive development. However, if reforms are passed, as they may be the 
publication of this piece, there is a possibility that foundations will move to new and pressing problems. As foundations shift priorities, will the funding that supported immigrant-serving nonprofits disappear? And if it does disappear, how will immigrant-serving nonprofits, posed with dozens of on-going problems related to immigrant access to health, education, and social services, maintain the capacity to register, educate, and mobilize immigrant voters? As these questions lie at the intersection of nonprofit practice and scholarship, their answers must also be a priority for researchers, practitioners, and foundations alike.

\section{References}

Anderson, E. 2008. "Experts, Ideas, and Policy Change: The Russell Sage Foundation and Small Loan Reform, 1900-1941." Theory \& Society 37(3):271-310.

Beltran, C. 2010. The Trouble with Unity: Latino Politics and the Creation of Identity. New York: Oxford University Press.

Berry, J. M. 1999. The New Liberalism: The Rising Power of Citizen Groups. Washington, DC: Brookings Institution Press.

Bob, C. 2012. The Global Right Wing and the Clash of World Politics. New York: Cambridge University Press.

Burghart, D. 2012. "View from the Top: A Report on Six National Tea Party Organizations, Chapter 3." In Steep: The Precipitous Rise of the Tea Party, edited by L. Rosenthal and C. Trost, 67-96. Berkley, CA: University of California Press.

de Graauw, E., S. Gleeson, et al. 2012. Funding Immigrant Organizations: Suburban Free-Riding and Local Civic Presence. New York: Center for Nonprofit Strategy and Management Working Paper Series.

de Leon, E., M. Maronick, et al. 2009. Community-Based Organizations and Immigrant Integration in the Washington, DC Metropolitan Area. Washington, DC: Urban Institute.

Disch, L. 2012. “The Tea Party: A 'White Citizenship' Movement? Chapter 5.” In Steep: The Precipitous Rise of the Tea Party, edited by L. Rosenthal and C. Trost, 133-51. Berkeley, CA: University of California Press.

Dye, T. 2000. Top Down Policymaking. Washington, DC: CQ Press.

Ecklund, E. H., and J. Z. Park. 2005. "Asian American Community Participation and Religion: Civic Model Minorities." Journal of Asian American Studies 6(1):1-22.

Ferris, J. M., and H. J. Harmssen. 2009. Foundation Practices for Public Policy Engagement. Los Angeles: Center on Philanthropy and Public Policy, USC.

Garcia Bedolla, L. and M. Michelson. 2012. Mobilizing Inclusion. New Haven, CT: Yale University Press.

Gleeson, S., and I. Bloemraad. 2012. "Assessing the Scope of Immigrant Organizations: Official Undercounts and Actual Underrepresentation." Nonprofit and Voluntary Sector Quarterly 42(2):346-70.

Kingdon, J. W. 1995. Agendas, Alternatives, and Public Policies. Boston: Little, Brown \& Company. 
Lopez, M. H., and A. Gonzalez-Barrera. 2013. “Inside the 2012 Latino Electorate.” Pew Hispanic Center, June 3. Available at: http://www.pewhispanic.org/2013/06/03/inside-the-2012latino-electorate/.

Mandeville, J. 2007. "Public Policy Grant Making: Building Organizational Capacity among Nonprofit Grantees." Nonprofit and Voluntary Sector Quarterly 36(2):282-98.

Mcllwain, C., and S. Caliendo. 2012. Race Appeal: How Candidates Invoke Race in US Political Campaigns. Philadelphia, PA: Temple University Press.

Mintrom, M. 2000. Policy Enterpreneurs and School Choice. Washington, DC: Georgetown University Press.

Parker, C., and M. A. Barreto. 2013. Change They Can't Believe in: The Tea Party and Reactionary Politics in America. Princeton, NJ: Princeton University Press.

Postel, C. 2012. "The Tea Parties in Historical Perspective: A Conservative Response to a Crisis of Political Economy, Chapter 1." In Steep: The Precipitous Rise of the Tea Party, edited by L. Rosenthal and C. Trost, 25-46. Berkeley, CA: University of California Press.

Ramakrishnan, S. K., and C. Viramontes. 2006. Civic Inequalities: Immigrant Volunteerism and Community Organizations in California. San Francisco, CA: Public Policy Institute of California.

Reckhow, S. 2012. Follow the Money: How Foundation Dollars Change Public School Politics. New York: Oxford University Press.

Rhodes, J. 2012. An Education in Politics: The Origins and Evolution of No Child Left Behind. Ithaca, NY: Cornell University Press.

Roelofs, J. 2003. Foundations and Public Policy: The Mask of Pluralism. Albany, NY: State University of New York Press.

Sandfort, J. 2008. "Using Lessons from Public Affairs to Inform Strategic Philanthropy." Nonprofit and Voluntary Sector Quarterly 37(3):537-52.

Skocpol, T., and V. Williamson. 2013. The Tea Party and the Remaking of Republican Conservatism. New York: Oxford University Press.

Smith, B. 2010. "ACORN 'dissolved as a National Structure'." Politico, February 22. Retrieved April 1, 2013, 2012: http://www.politico.com/blogs/bensmith/0210/

ACORN_dissolved_as_a_national_structure.html.

Teles, S. M. 2009. The Rise of the Conservative Legal Movement. Princeton, NJ: Princeton University Press.

Uhlaner, C., B. Caine, et al. 1989. "Political Participation of Ethnic Minorities in the 1980s." Political Behavior 11(3):195-213.

Vaughan, S. K., and S. Arsneault. 2014. Managing Nonprofit Organizations in a Policy World. Washington, DC: CQ Press/Sage.

Weidenbaum, M. 2009. The Competition of Ideas. New Brunswick, NJ: Transaction Publishers.

Weissert, C. S., and J. H. Knott. 1995. "Foundations' Impact on Policy Making: Results from a Pilot Study." Health Affairs 14(4):275-86.

Williamson, V., T. Skocpol, et al. 2011. "The Tea Party and the Remaking of Republican Conservatism." Perspectives on Politics 9(1):25-43. 